\title{
Quantification of Heavy Metal Accumulation in Edible Wild-Mushrooms in Copperbelt and Western Provinces of Zambia
}

\author{
Indra S. Singh, Christopher Nyau \\ Chemistry Department, School of Mathematics and Natural Sciences, The Copperbelt University, Kitwe, Zambia \\ Email: indra@cbu.ac.zm, Chris tophernyau@gmail.com
}

How to cite this paper: Singh, I.S. and Nyau, C. (2020) Quantification of Heavy Metal Accumulation in Edible Wild-Mushrooms in Copperbelt and Western Provinces of Zambia. Journal of Environmental Protection, 11, 1-12.

https://doi.org/10.4236/jep.2020.111001

Received: October 20, 2019

Accepted: December 31, 2019

Published: January 3, 2020

Copyright $\odot 2020$ by author(s) and Scientific Research Publishing Inc. This work is licensed under the Creative Commons Attribution International License (CC BY 4.0).

http://creativecommons.org/licenses/by/4.0/

\begin{abstract}
The mushrooms are highly regarded as one of the most nutritious foods across the globe but also recognized bio-accumulators of heavy metals. The nature and level of industrial activities are continually changing and affecting the environment adversely. The mushrooms are not an exception and may inevitably have heavy metal contaminations. In this vein, this study aimed to determine heavy metal $(\mathrm{Cu}, \mathrm{Ni}, \mathrm{Co}, \mathrm{Zn}, \mathrm{Pb}$, and $\mathrm{Cd})$ uptake levels in wild edible mushrooms from the sites with different economic activities. The wild mushrooms considered for this study included Tente (Amanita Zambiana), Ichikolowa (Termitomyces Titaniscus), and Kabansa (Lactarius Tataniscus). The analysis of heavy metal concentration was carried out using atomic absorption spectrometry (AAS). For the selected mushrooms, concentration ranges $\left(\mathrm{mg} \cdot \mathrm{kg}^{-1}\right.$ total dry weight $\left.(\mathrm{dw})\right)$ of $46.90-141.80$ for $\mathrm{Cu}, 0.10-6.60$ for Cd, $1.10-2.00$ for $\mathrm{Pb}, 19.00-38.90$ for $\mathrm{Zn}, 1.00-3.40$ for $\mathrm{Ni}$, and 44.80 79.70 for Co were obtained. However, for the respective soil samples, concentration ranges $\left(\mathrm{mg} \cdot \mathrm{kg}^{-1} \cdot \mathrm{dw}\right)$ of $51.00-279.40$ for $\mathrm{Cu}, 1.00$ - 99.50 for $\mathrm{Cd}, 8.00$ - 10.00 for Pb, 22.80 - 209.10 for $\mathrm{Zn}, 9.00$ - 33.70 for $\mathrm{Ni}$, and 60.00 - 111.90 for Co were obtained. To a certain degree, the concentrations reflected the impact of diversity in the surrounding activities. This study discovered that for the selected mushrooms, the contamination level of cadmium, cobalt, nickel, and copper exceeded the World Health Organization (WHO)/FAO (Food and Agriculture Organization) recommended limits. Although some minor aberrations from the prescribed limits were also observed in the case of copper and nickel. Further, the data established that the heavy metal concentrations in respective soils are not the sole determinant of concentrations in mushrooms. Thus, these findings merit attention as, in some cases, the extent of contamination has exceeded the WHO permissible limit, and it may pose a health risk to consumers.
\end{abstract}




\section{Keywords}

Contamination, Heavy Metals, Edible Mushrooms

\section{Introduction}

Perhaps never before, there has been as much thrust for healthy foods. In this vein, mushrooms are one of the few best selects. These are incredibly healthy food laden with nutritious dietary constituents but minimal calorie [1] [2] [3]. They are richly packed with a range of amino acids and vitamins, and also, have an abundance of proteins and fibers [4]. Remarkably, these edible fungi contain fat, which is predominantly composed of unsaturated fatty acids [5] [6]. Moreover, many of them have significant medicinal properties [7] [8].

However, mushrooms are infamous for accumulating heavy metals [9]. Many of the heavy metals are toxic to human health. For example, lead and cadmium have reportedly no health benefits to humans [10] [11]. A substantial fraction of inhaled or ingested lead is absorbed by the human system and primarily disseminated among blood and soft tissues subsequently [12]. Lead and cadmium are known to be amongst the most toxic metals. They adversely impact human health through neurotoxic and carcinogenic functions [13] [14] [15] [16] [17]. Further, Cadmium has also been reported to have an adverse effect on several vital human organs [14].

As far as cobalt is concerned, it is essential biochemically and also part of vitamin B-12. However, some studies have reported adverse cardiovascular effects caused by cobalt toxicity [18] [19]. For robust health, an adequate amount of zinc is critically essential. In effect, deficiencies in zinc may cause many diseases [20]. However, instances of acute and chronic zinc poisoning pertaining to the cellular system have also been reported [21].

Nickel happens to be yet another health-unfriendly metal. The exposure to nickel-polluted environments causes a range of pathological problems such as lungs and nasal cancers [22]. In the past, nickel was even branded as "Allergen of the Year" [23]. Copper is considered essential for good health, and it has also been reported that its intakes up to $6-7 \mathrm{mg} \cdot \mathrm{Cu} \cdot \mathrm{day}^{-1}$ are not linked with adverse effects on human health [24]. However, exposer to excessive levels may have adverse effects. In this context, a case is citable, where a severe liver disease was developed due to excessive intake of $\mathrm{Cu}$ [25].

The mushrooms are consumed worldwide, and Zambia is not an exception. It is common for the rural populace in tropical Africa to use edible and medicinal mushrooms for their survival and trade [26]. It is noteworthy that mushrooms have an interesting capability to fragment organic materials considerably and bio-accumulate heavy metals. They can be an instrument to estimate the degree of pollution [27]. However, the review paper [28] shows that it is difficult to single out any one mushroom species as an indicator of pollution level. 
In this context, therefore, it becomes relevant to investigate the concentrations of heavy metals and how their uptake varies with the diversity of human activities in the surroundings. Another reason this study considered $\mathrm{Ni}, \mathrm{Cd}, \mathrm{Co}, \mathrm{Zn}$, $\mathrm{Cu}$, and $\mathrm{Pb}$ is because these metals, by and large, characterize a dependable guide of contamination indicators [27]. Further, some of these metals are significantly essential for living organisms, while some of them, such as cadmium and lead, are significantly toxic even in small amounts [29].

Because of fascinating attributes of mushrooms and their various preparations clubbed with well-established mushroom delicacies in many cultures of the world, quite a good number of investigations on heavy metal pollution in wild mushrooms have already been carried out [30] [31] [32] [33] [34]. Zambia is a tropical country with a long rainy season and endowed with the right conditions for the growth of almost all kinds of mushrooms. Thus, Zambia has a vast potential for producing mushrooms. Indeed, edible mushrooms constitute an important component of the Zambian diet.

Today, the agricultural and industrial products are not limited to national boundaries and are consumed globally, and hence any contaminated product may have global implications. Further some of the heavy metals have adverse effects on human health. Moreover, Zambian studies on heavy metal contamination of mushrooms are inadequate and insufficient. Because of the above reasons, this study aimed to investigate the extent of heavy metal contamination in commonly consumed edible mushrooms and deviation from WHO recommended limits. Further, it also aimed to investigate if there was any correlation between the diversity of human activities on the contamination levels of metals in the mushrooms.

\section{Materials and Methods}

\subsection{Sample Sites and Sample Size}

The mushroom samples were collected from two randomly selected sites in clean polyethylene bags. The criteria used for the selection of sites based on the variation in human activities. The sampling site comprised Forests in Solwezi (latitude: $-12^{\circ} 2499^{\prime} \mathrm{S}$, longitude: $26^{\circ} 000.00^{\prime} \mathrm{E}$ ) in North Western Province and Mpongwe (latitude: $13^{\circ} 3032.9^{\prime} \mathrm{S}$, longitude: $28^{\circ} 9^{\prime} 18.14^{\prime} \mathrm{E}$ ) in Copperbelt province of Zambia. Solwezi is known for the intensive mining industry, while agriculture is a mainstay in Mpongwe. There were three species of mushrooms considered for this study. They include Amanita zambiana, Lactarius titaniscus, and Termitomyces titaniscus, all of them belong to amanitaceae family. The simple random sampling technique was used to select the different species of mushrooms from particular sites. Five samples of each species of mushrooms were collected every month from the respective sites. The samples were collected for three consecutive months (December, January, and February). Thus a total of fifteen samples were collected for each species.

From each sampling site of mushrooms, $0.2 \mathrm{Kg}$ of soil samples from a depth 
of $0.2 \mathrm{~m}$ from the surface were collected in clean polyethylene bags and labeled carefully. The soil samples were collected simultaneously with that of mushrooms. Thus, a total of 15 soil samples were also collected corresponding to each mushroom. All the mushroom samples considered in this study were edible wild mushrooms grown naturally.

\subsection{Sample Digestion and Analysis}

After collection, each mushroom sample was individually cleaned with double distilled water. The flower parts of the mushroom samples for each species were cut into smaller pieces with a clean knife and placed in a labeled glass container. These samples were then oven-dried at $105^{\circ} \mathrm{C}$ overnight. The respective dried mushroom samples were thoroughly blended into the powdered form using a commercial blender.

All the chemicals and standards used in this study were analytical grade and procured from Inorganic Ventures (Christiansburg, VA 24073, USA). A $1.0 \mathrm{~g}$ sample of Powdered mushroom was added to a beaker containing $15 \mathrm{~mL}$ mixture of $\mathrm{HNO}_{3}(70 \%), \mathrm{H}_{2} \mathrm{SO}_{4}(70 \%)$ and $\mathrm{HClO}_{4}(65 \%)$ in a proportion of 5:1:1 and digested at $80^{\circ} \mathrm{C}$ following the reported method [35] until the solution became transparent [36]. Subsequently, the solution was cooled down to room temperature and filtered through a Whatman No.42 filter paper. The filtrate was then diluted to $50 \mathrm{~mL}$ with double distilled water. The digestion of soil samples were also carried out following the same procedure as dried mushroom powders.

The concentration determination of lead, nickel, cobalt, cadmium, copper, and zinc in the diluted filtrate for mushroom and respective soil samples was carried out using an atomic absorption spectrophotometer (PerkinElmer Inc. -AAnalyst 200) and specific lamp for respective metal. The analysis was carried out at the Mining and Geological Laboratory at the Copperbelt University.

The necessary measures were taken to ascertain the correctness of the results. In this vein, therefore, repetitive analysis of samples was carried out against the reference standards procured from Inorganic Ventures (Christiansburg, VA 24073, USA) for all the heavy metals considered in this study.

\section{Results and Discussion}

\subsection{Results}

The results of the mean concentration of heavy metals $(\mathrm{Cu}, \mathrm{Cd}, \mathrm{Pb}, \mathrm{Zn}, \mathrm{Ni}$, and $\mathrm{Co}$ ) in the samples of mushrooms from two study sites are stipulated in tables below in $\mathrm{mg} \cdot \mathrm{kg}^{-1}$ dry weight $(\mathrm{dw})$. For all the mushroom samples, results were compared with FAO/WHO standard limits.

\subsubsection{Mean Heavy Metal Concentration in Edible Mushroom Samples from Mpongwe}

The heavy metal concentration analysis in mushroom samples from the Mpongwe area is stipulated in Table 1 below. 
Table 1. Mean heavy metal concentrations in wild edible mushrooms from Mpongwe area expressed in $\mathrm{mg} \cdot \mathrm{kg}^{-1}$ dry weight.

\begin{tabular}{ccccc}
\hline $\begin{array}{c}\text { Heavy } \\
\text { Metal }\end{array}$ & $\begin{array}{c}\text { Amanita } \\
\text { zambiana } \\
(\mathrm{AMZ})\end{array}$ & $\begin{array}{c}\text { Termitomyces } \\
\text { titaniscus } \\
(\mathrm{TET})\end{array}$ & $\begin{array}{c}\text { Lactarius } \\
\text { titaniscus } \\
(\mathrm{LAT})\end{array}$ & $\begin{array}{c}\text { FAO/WHO Standards for } \\
\text { Mushroom }\end{array}$ \\
\hline $\mathrm{Cu}$ & $118.5 \pm 5.56$ & $91.4 \pm 0.35$ & $46.9 \pm 0.76$ & 73 \\
$\mathrm{Cd}$ & $0.13 \pm 0.00$ & $6.63 \pm 0.03$ & $4.27 \pm 0.10$ & 0.3 \\
$\mathrm{~Pb}$ & $1.33 \pm 0.99$ & $1.52 \pm 0.39$ & $1.96 \pm 0.11$ & 2.0 \\
$\mathrm{Zn}$ & $29.18 \pm 5.87$ & $18.98 \pm 1.62$ & $38.88 \pm 3.03$ & 40 \\
$\mathrm{Ni}$ & $3.36 \pm 1.45$ & $1.25 \pm 0.35$ & $2.22 \pm 1.33$ & 1.5 \\
$\mathrm{Co}$ & $56.88 \pm 1.33$ & $44.80 \pm 0.62$ & $76.52 \pm 0.34$ & 50 \\
\hline
\end{tabular}

\subsubsection{Mean Heavy Metal Concentration in Edible Mushroom Samples from Solwezi}

The heavy metal concentrations obtained in mushroom samples from Solwezi area are stipulated in Table 2 below.

\subsubsection{Mean Heavy Metal Concentrations in Soil Samples Collected froms from Solwezi and Mpongwe}

The heavy metal concentrations obtained in soils samples from Mpongwe and solwezi are stipulated Table 3 below.

\subsection{Discussion of Results}

The comparison between the heavy metal concentration in mushrooms and the corresponding soil samples do not show direct proportionality. For example, TET mushroom (Table 2) and corresponding soil sample (Table 3) from Solwezi have highest $\mathrm{Cu}$ concentration but AMZ from Solwezi (Table 2) does not have with lowest $\mathrm{Cu}$ concentration while the corresponding soil has the lowest $\mathrm{Cu}$ concentration (Table 3). Several other aberrations are observed with correlating the concentrations in mushrooms (Table 1 and Table 2) and respective soil samples. In a nutshell, there is no proportional relationship between the heavy metal concentration in the mushroom and corresponding soil.

The concentrations of $\mathrm{Cu}, \mathrm{Co}$, and $\mathrm{Cd}$ for mushroom samples from both Mpongwe (Table 1) and Solwezi (Table 2) were found to be higher than the WHO recommended limits. Notably, the extent of cadmium contamination in TET and LAT from both the sites has been significantly high and merits to be underlined. It warrants attention because cadmium reportedly affects many human organs [14]. However, the extent of Cd concentration in Mpongwe samples is much greater as compared to those from Solwezi. Intense agricultural activities characterize the Mpongwe site, and the higher concentration of Cd may be attributed to the extensive use of nitrogenous fertilizers. In this context, it has been reported [37] that nitrogen fertilizers increase Cd concentrations in soil. Although a mushroom species, namely Agaricus macrosporus have been reported [38] to have a much higher concentration of Cd in a study from Spain. Further, the Cd concentrations in soil samples in Mpongwe (Table 3) are not 
Table 2. Mean heavy metal concentrations in edible mushroom from Solwezi area expressed in $\mathrm{mg} \cdot \mathrm{kg}^{-1}$ dry weight.

\begin{tabular}{ccccc}
\hline $\begin{array}{c}\text { Heavy } \\
\text { Metals }\end{array}$ & $\begin{array}{c}\text { Amanita } \\
\text { zambiana } \\
(\mathrm{AMZ})\end{array}$ & $\begin{array}{c}\text { Termitomyces } \\
\text { titaniscus } \\
(\mathrm{TET})\end{array}$ & $\begin{array}{c}\text { Lactarius } \\
\text { titaniscus } \\
(\mathrm{LAT})\end{array}$ & $\begin{array}{c}\text { FAO/WHO for } \\
\text { Mushroom }\end{array}$ \\
\hline $\mathrm{Cu}$ & $113.03 \pm 5.75$ & $141.78 \pm 0.76$ & $79.98 \pm 0.35$ & 73 \\
$\mathrm{Cd}$ & $0.12 \pm 0.00$ & $2.11 \pm 0.11$ & $3.67 \pm 0.03$ & 0.3 \\
$\mathrm{~Pb}$ & $1.26 \pm 0.99$ & $0.64 \pm 0.11$ & $1.12 \pm 0.39$ & 2.0 \\
$\mathrm{Zn}$ & $33.74 \pm 5.87$ & $21.80 \pm 3.03$ & $31.18 \pm 1.62$ & 40 \\
$\mathrm{Ni}$ & $1.02 \pm 1.23$ & $1.38 \pm 1.33$ & $1.12 \pm 0.35$ & 1.5 \\
$\mathrm{Co}$ & $79.68 \pm 1.03$ & $64.68 \pm 1.53$ & $49.80 \pm 0.62$ & 50 \\
\hline
\end{tabular}

Mean heavy metal concentrations in Soils samples collected from Mpongwe and Solwezi.

Table 3. Mean heavy metal concentrations in Soils samples collected from Mpongwe area and Solwezi road area in $\mathrm{mg} \cdot \mathrm{kg}^{-1}$ dry weight.

\begin{tabular}{ccccccc}
\hline \multirow{2}{*}{ Heavy metal } & \multicolumn{3}{c}{ From Solwezi road Area } & \multicolumn{3}{c}{ From Mpongwe area } \\
\cline { 2 - 7 } & AMZ & LAT & TET & AMZ & LAT & TET \\
\hline $\mathrm{Cu}$ & 50.99 & 89.86 & 279.39 & 99.19 & 101.86 & 112.39 \\
$\mathrm{Cd}$ & 33.97 & 11.46 & 99.48 & 0.97 & 1.76 & 9.48 \\
$\mathrm{~Pb}$ & 9.59 & 9.03 & 9.98 & 9.19 & 8.03 & 9.28 \\
$\mathrm{Zn}$ & 79.78 & 22.80 & 209.15 & 32.09 & 23.20 & 41.15 \\
$\mathrm{Ni}$ & 11.00 & 33.70 & 9.08 & 10.89 & 33.73 & 11.08 \\
$\mathrm{Co}$ & 59.98 & 101.86 & 78.07 & 91.98 & 111.86 & 87.07 \\
\hline
\end{tabular}

higher than those in Solwezi soil samples (Table 3). These results further reinforce that the metal concentrations in mushrooms are not consistently dependent on the corresponding soil sample concentrations.

The $\mathrm{Cu}$ content (Table 1 and Table 2) is much higher than the reported range of 21.1 to $40 \mu \mathrm{g} / \mathrm{g}$ [39]. Some other workers have also reported similar results [32] [40]. Further, the Solwezi sample has the highest $\mathrm{Cu}$ concentration. The higher $\mathrm{Cu}$ concentration may be ascribed to the intensive copper mining in Solwezi. The concentration of Co (Table 1 and Table 2) is much higher as compared to some of the reported ranges of $0.28-1.32 \mu \mathrm{g} / \mathrm{g}[41]$ and $0.15-6.03 \mu \mathrm{g} / \mathrm{g}$ [42]. The higher concentration of Co may be attributed to extensive mining activities in Copperbelt and Western provinces of Zambia.

The Ni concentrations were found to be within the WHO recommended limits in all the samples from Solwezi (Table 2), but they exceeded in AMZ and LAT samples from Mpongwe (Table 1). A range of 1.19 - $54.12 \mu \mathrm{g} / \mathrm{g}$ concentration has been reported [43]. The higher concentrations of $\mathrm{Ni}$ can be due to the agricultural activities in Mpongwe. It has been reported that fertilizer can be one of the significant sources of $\mathrm{Ni}$ into soils [44].

The $\mathrm{Pb}$ and $\mathrm{Zn}$ concentrations in all the mushroom samples from both Mpongwe (Table 1) and Solwezi (Table 2) were found to be within the WHO 
prescribed limits. These results fall within some other $\mathrm{Pb}$ concentration ranges of $0.40-2.80 \mu \mathrm{g} / \mathrm{g}$ [45], $0.75-7.77 \mu \mathrm{g} / \mathrm{g}$ [41] and $0.67-4.43 \mu \mathrm{g} / \mathrm{g}$ [32] as reported earlier. In the same vein, The $\mathrm{Zn}$ concentrations obtained in this study fall within the earlier reported $\mathrm{Zn}$ concentrations ranges of $40.3-64.4 \mu \mathrm{g} / \mathrm{g}$ [46] and 29.3 - $158 \mu \mathrm{g} / \mathrm{g}$ [42].

The findings of the study strongly support the fact that the heavy metal concentrations differ significantly with the species of mushrooms in the same sampling areas. For example, $\mathrm{Cu}$ concentrations in AMZ, TET, and LAT from Solwezi (Table 2) are $113.03 \pm 5.75,141.78 \pm 0.76,79.98 \pm 0.35 \mathrm{mg} \cdot \mathrm{kg}^{-1} \cdot \mathrm{dw}$, respectively. Similarly, $\mathrm{Cu}$ concentrations in AMZ, TET, and LAT from Mpongwe (Table 1) are $118.5 \pm 5.56,91.4 \pm 0.35$, and $46.9 \pm 0.76 \mathrm{mg} \cdot \mathrm{kg}^{-1} \cdot \mathrm{dw}$, respectively. Such patterns are also observed with other metals as pictorially depicted in Figure 1 and Figure 2. The Cd concentrations in AMZ from both the sites are much lower and, in fact, below the WHO limits. Thus, AMZ may be considered to have the lowest tendency for bioaccumulation of cadmium. These facts also strongly reinforce the fact that different species of mushrooms have a significantly different tendency for bioaccumulation of metals. It has been reported [47] that the biosorption efficiency of $P$. eous for heavy metals is significantly variable.

Generally, $\mathrm{Cu}$ concentrations are quite high (Figure 1 and Figure 2) as compared to many reported studies. The higher $\mathrm{Cu}$ Concentration can be attributed to the higher copper content in the soil in Zambia, which has vast Copper resources and is a country with intensive copper mining activities. The other variations in heavy metal concentrations for different samples may be due to the difference in geological location and because of the free drained soils and waste due to mining activities.

Although $\mathrm{Pb}$ and $\mathrm{Zn}$ are within the permissible range set by $\mathrm{WHO}$, the higher concentrations of $\mathrm{Cu}, \mathrm{Ni}, \mathrm{Co}$, and $\mathrm{Cd}$ are a matter of concern. The most worrisome is the higher concentrations of $\mathrm{Cd}$ as it is highly toxic even in trace

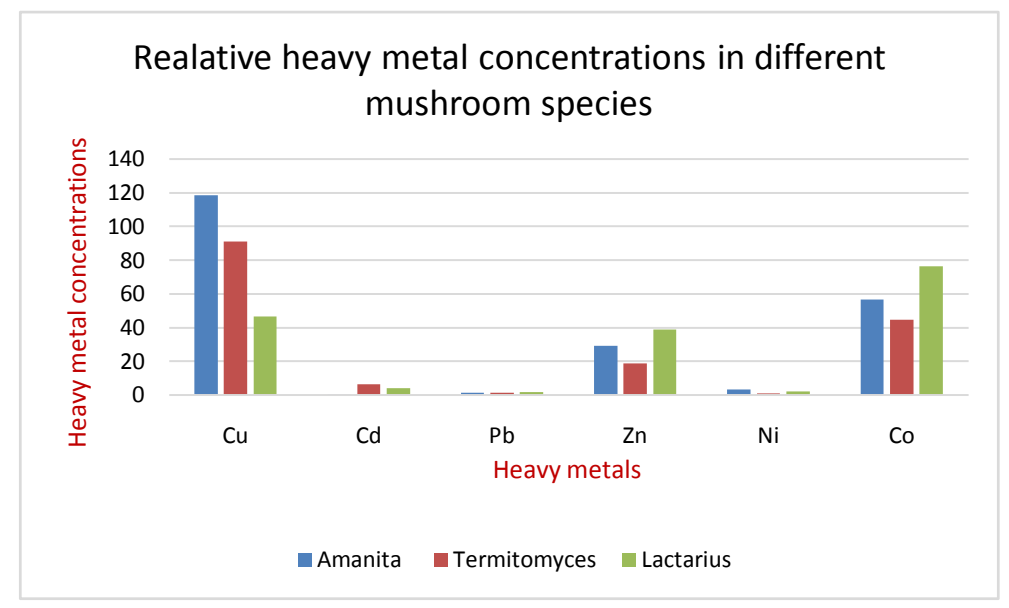

Figure 1. The heavy metal concentration $\left(\mathrm{mg} \cdot \mathrm{kg}^{-1} \cdot \mathrm{dry} \cdot\right.$ weight $)$ in edible mushrooms from the Mpongwe smpling site. 


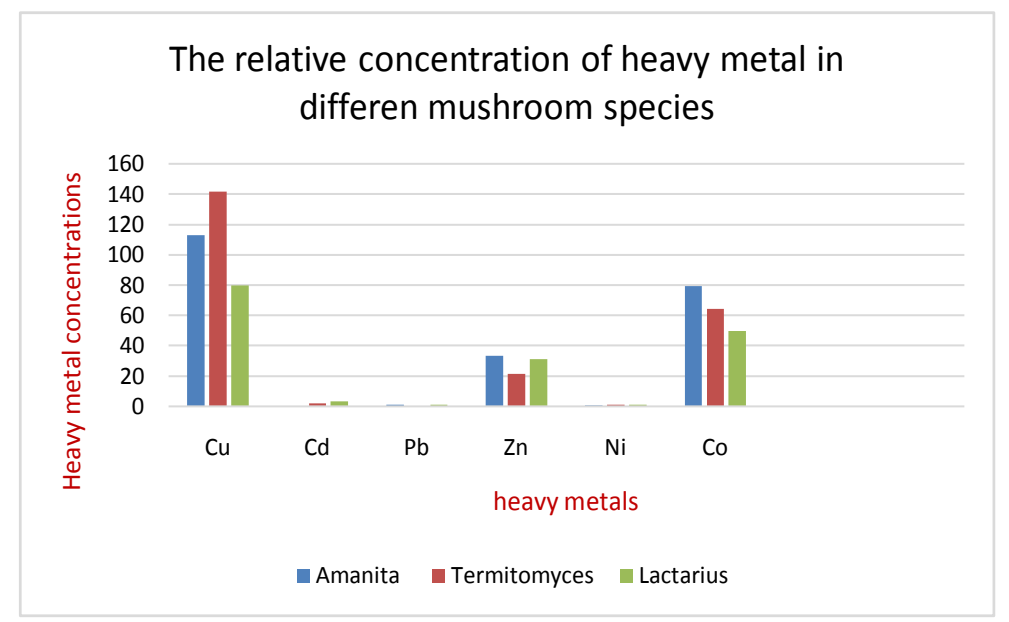

Figure 2. The heavy metal concentration $\left(\mathrm{mg} \cdot \mathrm{kg}^{-1} \cdot \mathrm{dry} \cdot\right.$ weight $)$ in edible mushrooms from the Solwezi smpling site.

amounts [48] [49] [50]. Moreover, the agricultural products have access to global markets these days and may affect consumers across the globe. Therefore, it is essential to embark on measures to reduce bioavailable $\mathrm{Cd}$ to mitigate the problem. The alleviation measures may include the control of biosorption and bioavailable heavy metals in mushroom growing soils by reducing agricultural fertilizers and mining activities in the surroundings.

\section{Conclusion}

In conclusion, the concentrations of $\mathrm{Cu}, \mathrm{Cd}, \mathrm{Co}$, and $\mathrm{Ni}$ in selected mushroom species were higher than the $\mathrm{WHO}$ recommended limits, while $\mathrm{Pb}$ and $\mathrm{Zn}$ concentrations were below the WHO set limits. The higher than acceptable concentrations are a matter of serious concern. The higher cadmium concentration may have a devastating health hazard. Therefore, corrective measures are warranted to reduce the contamination level to WHO suggested limits. The data of this study show that there is no consistent proportionality relationship between the heavy metal concentrations in a mushroom and corresponding soil sample. The findings are significant as they are reflective of the true picture of heavy metal contamination levels in some mushroom species and health implications to consumers. The study also entails the possible correlation between heavy metal concentration and type of economic activities such as farming and mining. Further, it may help consumers to select relatively safe species. This study strongly establishes the fact that different mushroom species have different biosorption efficiency for particular heavy metals.

\section{Acknowledgements}

The authors acknowledge the financial and logistical support received from the Coppebelt University. We also acknowledge with gratitude the analytical facilities availed from Mining and geological labs at the Copperbelt University. 


\section{Conflicts of Interest}

The authors declare no conflicts of interest regarding the publication of this paper.

\section{References}

[1] Racz, L., Papp, L., Prokai, B. and Kovacz, Z. (1996) Trace Element Determination in Cultivated Mushrooms: An Investigation of Manganese, Nickel, and Cadmium Intake in Cultivated Mushrooms Using ICP Atomic Emission. Microchemical Journal, 54, 444-451. https://doi.org/10.1006/mchj.1996.0121

[2] Barbisan, L.F., Spinardi-Barbisan, A.L.S., Moreira, E.L.T., Salvadori, D.M.F., Ribeiro, L.R. and Eira, A.F. (2003) Agaricus blazei (Himematsutake) Does Not Alter the Development of Rat Diethylnitrosamine-Initiated Hepatic Preneoplastic Foci. Cancer Science, 94, 188-192. https://doi.org/10.1111/j.1349-7006.2003.tb01417.x

[3] Bellini, M.F., Giacomini, N.L., Eira, A.F., Ribeiro, L. R. and Mantovani, M.S. (2003) Anticlastogenic Effect of Aqueous Extracts of Agaricus blazei on CHO k1 Cells, Studying Different Developmental Phases of the Mushroom. Toxicology in Vitro, 17, 465-469. https://doi.org/10.1016/S0887-2333(03)00043-2

[4] Sadler, M. (2003) Nutritional Properties of Edible Fungi. Nutrition Bulletin, 28, 305-308. https://doi.org/10.1046/j.1467-3010.2003.00354.x

[5] Yilmaz, N.M., Solmaz, I. and El Mastas, M. (2006) Fatty Acid Composition in Some Wild Ediblemushrooms Growing in the Middly Black Region of Turkey. Food Chemistry, 99, 168-174. https://doi.org/10.1016/j.foodchem.2005.08.017

[6] Pedneault, K.P., Gosselia, A. and Tweddel, R.J. (2006) Fatty Acid Composition of Lipids from Mushrooms Belonging to the Family of Boletaceae. Mycological Research, 110, 1179-1183. https://doi.org/10.1016/j.mycres.2006.05.006

[7] Wasser, S.P. and Weis, A.L. (1999) Medicinal Properties of Substances Occurring in Higher Basidiomycete Mushrooms: A Modern Prospective. Critical Reviews in Immunology, 19, 65-96. https://doi.org/10.1615/CritRevImmunol.v19.i1.30

[8] Wasser, S.P., Weis, A.L. and Krast, P. (1999) Medicinal Values of the Genus Pleurotus (Fr) (Agaricales S. R. Basidiomycetes). International Journal of Medicinal Mushrooms, 1, 69-70. https://doi.org/10.1615/IntJMedMushrooms.v1.i1.50

[9] Kalac, P. and Svoboda, L.A. (2000) Review of Trace Element Concentrations in Edible Mushrooms. Food Chemistry, 62, 273-281. https://doi.org/10.1016/S0308-8146(99)00264-2

[10] Draghici, C., Coman, G., Jelescu, C., Dima, C. and Chirila, E. (2010) Heavy Metals Determination in Environmental and Biological Samples, In: Environmental Heavy metal Pollution and Effects on Child Mental Development-Risk Assessment and Prevention Pelagic Fish Species from the Strategies, NATO Advanced Research Workshop, Sofia, Bulgaria, 28April-1 May 2010. https://doi.org/10.1007/978-94-007-0253-0_9

[11] Vieira, C., Morais, S., Ramos, S., Delerue-Matos, C. and Oliveira, M.B.P.P. (2011) Mercury, Cadmium, Lead and Arsenic Levels in Three Pelagic Fish Species from the Atlantic Ocean: Intra and Inter-Specific Variability and Human Health Risk for Consumption. Food and Chemical Toxicology, 49, 923-932. https://doi.org/10.1016/j.fct.2010.12.016

[12] Ming-Ho, Y. (2005) Environmental Toxicology: Biological and Health Effects of Pollutants. 2nd Edition, CRC Press LLC, Boca Raton, FL.

[13] Agency for Toxic substance and Disease Registry (ASTDR) (2004) Toxicological 
Profile for Copper. U.S. Department of Health and Human Services, Public Health Service, Centers for Disease Control. Atlanta, GA.

[14] Agency for Toxic substance and Disease Registry (ASTDR) (2008) Draft Toxicological Profile for Cadmium. U.S. Department of Health and Human Services, Public Health Service, Centers for Disease Control. Atlanta, GA.

[15] Castro-Gonzalez, M.I. and Mendez-Armenta, M. (2008) Heavy Metals: Implications Associated to Fish Consumption. Environmental Toxicology and Pharmacology, 26, 263-271. https://doi.org/10.1016/j.etap.2008.06.001

[16] Jomova, K. and Valko, M. (2010) Advances in Metal-Induced Oxidative Stress and Human Disease. Toxicology, 283, 65-87. https://doi.org/10.1016/j.tox.2011.03.001

[17] Toker, E.J., Bembrahim Tallaa, L. and Waalkes, M.P. (2011) Metal Ions in Human Cancer Development. Metal Ions in Life Sciences, 8, 375-401. https://doi.org/10.1039/9781849732116-00375

[18] Bonenfant, J.L., Auger, C. and Miller, G. (1969) Quebec Beer-Drinkers' Myocardosis: Pathological Aspects. Annals of the New York Academy of Sciences, 156, 577-582. https://doi.org/10.1111/j.1749-6632.1969.tb16752.x

[19] Alexander, C.S. (1969) Cobalt and Heart. Annals of Internal Medicine, 70, 411-413. https://doi.org/10.7326/0003-4819-70-2-411

[20] Fraker, P.J., King, L.E., Laakko, J. and Vollmer, T.L. (2000) The Dynamic Link between the Integrity of the Immune System and Zinc Status. The Journal of Nutrition, 130, 13995-14065. https://doi.org/10.1093/jn/130.5.1399S

[21] Pagani, A., Villarreal, L., Capdevila, M. and Astrian, S. (2007) The Saccharomyces Cerevisiae Crs 5 Metallotionein Metal-Binding Abilities and Its Role in the Response to Zinc Overload. Molecular Microbiology, 1, 256-269. https://doi.org/10.1111/j.1365-2958.2006.05510.x

[22] Oller, A.R., Costa, M. and Oberdorster, G. (1997) Carcinogenicity Assessment of Selected Nickel Compounds. Toxicology and Applied Pharmacology, 143, 152-166. https://doi.org/10.1006/taap.1996.8075

[23] Gillete, B. (2008) Nickel Named "Allergen of the Year". ACDS Adds to the List of Substances Warranting More Attention. Dermatology Times, 4, 15-16.

[24] O’Connor, J.M., Chopra, J.M., Harvey, M., Majsak-Newman, L.J., Fairweather-tait, G., Bugel, S.J., Sandstorm, S., Rock, B., Mazur, E., Rayssiguier, A. and Stain, J.J. (2000) Copper Supplementation in Humans Does Not Affect the Susceptibility of Low Density Lipoprotein to in Vitro Induced Oxidation (FOODCUE Project). Free Radical Biology and Medicine, 29, 1129-1134. https://doi.org/10.1016/S0891-5849(00)00409-3

[25] O’Donohue, J.W., Reid, M.A., Varghese, A., Portmann, B. and Williams, R. (1993) Micronodular Cirrhosis and Acute Liver Failure Due to Chronic Copper Self-Intoxication. European Journal of Gastroenterology and Hepatology, 5, 561-562.

[26] Malaisse, F. (2010) How to Live and Survive in Zambezian Open Forest (Miombo Ecoregion). Gembloux, Presses, 422.

[27] Sesli, E. and Tüzen, M. (1999) Levels of Trace Elements in the Fruiting Bodies of Macrofungi Growing in the East Black Sea Region of Turkey. Food Chemistry, 65, 453-460. https://doi.org/10.1016/S0308-8146(98)00194-0

[28] Wondratschek, I. and RoÈ der, U. (1993) Monitoring of Heavy Metals Insoils by Higher Fungi. In: Markert, B., Ed., Plants as Biomonitors. Indicators for Heavy Metals in the Terrestrial Environment, Wiley, Weinheim, Germany, 345-363.

[29] Schroeder, H.A. (1973) The Trace Elements and Nutrition. Faber and Faber, Lon- 
don.

[30] Tüzen, M., Turkekul, I., Hasdemir, E., Mendil, D. and Sari, H. (2003) Atomic Absorption Spectrometric Determination of Trace Metal Contents of Mushroom Samples from Tokat, Turkey. Analytical Letters, 36, 1401-1410.

https://doi.org/10.1081/AL-120021095

[31] Radulescu, C., Stihi, C., Busuioc, G., Gheboianu, A.I. and Popescu, I.V. (2010) Studies Concerning Heavy Metals Bioaccumulation of Wild Edible Mushrooms from Industrial Area by Using Spectrometric Techniques. Bulletin of Environmental Contamination and Toxicology, 84, 641-646. https://doi.org/10.1007/s00128-010-9976-1

[32] Zhu, F., Qu, L., Fan, W., Qiao, M., Hao, H. and Wang, X. (2011) Assessment of Heavy Metals in Some Wild Edible Mushrooms Collected from Yunnan Province, China. Environmental Monitoring and Assessment, 179, 191-199. https://doi.org/10.1007/s10661-010-1728-5

[33] Liu, B., Huang, Q., Cai, H., Guo, X., Wang, T. and Gui, M. (2015) Study of Heavy Metal Concentrations in Wild Edible Mushrooms in Yunnan Province, China. Food Chemistry, 188, 294-300. https://doi.org/10.1016/j.foodchem.2015.05.010

[34] Akin, C., Munevver, C. and Mahmut, C. (2010) The Heavy Metal Content of Wild Edible Mushroom Samples Collected in Canakkale Province, Turkey. Biological Trace Element Research, 134, 212-219. https://doi.org/10.1007/s12011-009-8464-0

[35] Allen, S.E., Grimshaw, H.M. and Rowland, A.P. (1986) Methods in Plant Ecology. In: Moore, P.D. and Chapman, S.B., Eds., Chemical Analysis, Blackwell Scientific Publication, Oxford, London, 285-344.

[36] American Public Health Association (2005) Standard Methods for the Examination of Water and Wastewater. American Public Health Association, Washington DC.

[37] Wangstrand, H., Erikson, J. and Oborn, I. (2007) Cadmium Concentration in Winter Wheat as Affected by Nitrogen Fertilization. European Journal of Agronomy, 26, 209-214. https://doi.org/10.1016/j.eja.2006.09.010

[38] Melgar, M.J., Diaz, J.A. and Ma, G. (2016) Cadmium in Edible Mushrooms from NW Spain: Bioconcentratin Factors and Consumer Health Implications. Food and Chemical Toxicology, 88, 13-20. https://doi.org/10.1016/j.fct.2015.12.002

[39] Sivrikaya, H., Bacak, L., Saracbasi, A., Toroglu, L. and Eroglu, H. (2002) Trace Elements in Pleurotus Sajorcaju Cultivated on Chemithermomechanical Pulp for Bioleaching. Food Chemistry, 79, 173-176. https://doi.org/10.1016/S0308-8146(02)00128-0

[40] Yamaç, M., Yildiz, D., Sarıkürkçü, C., Çelikkollu, M. and Solak, M.H. (2007) Heavy Metals in Some Edible Mushrooms from the Central Anatolia, Turkey. Food Chemistry, 103, 263-267. https://doi.org/10.1016/j.foodchem.2006.07.041

[41] Tuzen, M. (2003) Determination of Heavy Metals in Soil, Mushroom and Plant Samples by Atomic Absorption Spectrometry. Microchemical Journal, 74, 289-297. https://doi.org/10.1016/S0026-265X(03)00035-3

[42] Isiloglu, M., Yilmaz, F. and Merdivan, M. (2001) Concentration of Trace Elements in Wild Edible Mushrooms. Food Chemistry, 73, 169-175. https://doi.org/10.1016/S0308-8146(00)00257-0

[43] Sithole, M.H., Mugivhisa, L.L., Amoo, S.O. and Olowoyo, J.O. (2017) Pattern and Concentrations of Trace Metals in Mushrooms Harvested from Trace-Metal Polluted Soils in Pretoria, South Africa. South African Journal of Botany, 108, 315-320. https://doi.org/10.1016/j.sajb.2016.08.010 
[44] Mcllveen, W.D. and Negusanti, J.J. (1994) Nickel in Terrestrial Environment. Science of The Total Environment, 148, 109-138. https://doi.org/10.1016/0048-9697(94)90390-5

[45] Svoboda, L., Zimmermannova, K. and Kalac, P. (2000) Concentrations of Mercury, Cadmium, Lead and Copper in Fruiting Bodies of Edible Mushrooms in an Emission Area of Copper Smelter and a Mercury Smelter. Science of the Total Environment, 246, 61-67. https://doi.org/10.1016/S0048-9697(99)00411-8

[46] Mendil, D., O. D. Uluozlu, O. D., Hasdemir, E. and Caglar, A. (2004) Determination of Trace Elements on Some Wild Edible Mushroom Samples from Kastmonu, Turkey. Food Chemistry, 88, 281-285. https://doi.org/10.1016/j.foodchem.2004.01.039

[47] Suseem, S.R. and Mary, A.S. (2014) Biosorption of Heavy Metals Using Mushroom Pleurotus eous. Journal of Chemical and Pharmaceutical Research, 6, 2163-2168.

[48] Manca, D., Ricard, A.C., Trotter, B. and Chevalier, G. (1991) Studies of Lipid Peroxidation in Rat Tissues Following Administration of Low and Moderate Doses of Cadmium Chloride. Toxicology, 67, 303-323.

https://doi.org/10.1016/0300-483X(91)90030-5

[49] Casal Ino, E., Calzaretti, G., Blano, C.S. and Landriscin, C. (2002) Molecular Inhibitory Mechanism of Antioxidant Enzymes in Rat Liver and Kidney by Cadmium. Toxicology, 179, 37-50. https://doi.org/10.1016/S0300-483X(02)00245-7

[50] M’en Dez-Armenta, M., Barroso-Moguel, R., Villeda-Hernandez, J. and Nava-Ruiz, C. (2001) Histophatological Alterations in the Brain Regions of Rats after Perinatal Combined Treatment with Cadmium and Dexamethasone. Toxicology, 161, 189-199. https://doi.org/10.1016/S0300-483X(01)00349-3 